\title{
Does stage-3 chronic kidney disease matter? A systematic literature review
}

\author{
Pawana Sharma, Keith McCullough, Graham Scotland, Paul McNamee, Gordon Prescott,
} Alison MacLeod, Nick Fluck, William Cairns Smith, Corri Black

\begin{abstract}
Background

Stage-3 chronic kidney disease (CKD) is the first stage that is identifiable from a blood test alone. In the UK, it accounts for the majority of people on primary care CKD registers. It also represents a group of people who, in the past, would have gone unnoticed clinically. In order to support patients and plan services, the natural history of stage-3 CKD is important.

Aim

To systematically review the natural history of stage-3 CKD in order to describe all cause mortality, cardiovascular morbidity and mortality, and renal outcomes.

Design of study

Systematic review of the literature.

Method

MEDLINE and Embase databases were searched from 1998 to February 2009. Systematic reviews and cohort studies that included adults with stage-3 CKD were considered eligible. Studies were appraised and data extracted by one reviewer and checked by a second.

Results

Thirteen studies were identified including a total of 728328 people. The all-cause mortality rate varied from $6 \%$ in 3 years to $51 \%$ in 10 years and was higher in stage-3B CKD (4.8 per 100 person-years) than stage-3A CKD (1.1 per 100 person-years). The relative risk of mortality (all-cause mortality or cardiovascular disease [CVD] mortality) was higher in stage-3 CKD compared with no CKD, but the increase was small for those with stage-3A CKD (hazard ratio [HR] 1.2-1.7) and greater in stage 3B (HR 1.8-3.3). End-stage renal disease was rare ( $4 \%$ in 10 years) and renal progression was evident in $<20 \%$ of patients after 5 years.

\section{Conclusions}

For patients with stage- 3 CKD, risk of mortality was higher than for those without CKD, but the risk of progression was low. CKD registers provide an opportunity for GPs to assess the risk of patients developing CVD.

Keywords

chronic kidney disease; natural history; primary care systematic review.
\end{abstract}

\section{INTRODUCTION}

With prevalence studies currently estimating that around $5 \%$ of the adult population will have evidence of stage-3 or 'moderate' chronic kidney disease (CKD), ${ }^{1-7}$ the last 5 years has seen CKD become a major healthcare challenge. Commentators have described CKD as a 'major public health problem' and talked of an 'epidemic' ${ }^{8-10}$ Although there is some evidence that the prevalence in CKD is increasing, the change in epidemiology is essentially driven by an increase in detection and awareness. ${ }^{11}$

In 2002, the US Kidney Disease Outcomes Quality Initiative (KDOQI) proposed a definition of CKD with five stages that has been adopted internationally: 'kidney damage or decreased kidney function (glomerular filtration rate [GFR] $<60 \mathrm{~mL} / \mathrm{min} / 1.73 \mathrm{~m}^{2}$ ) for $\geq 3$ months' (Table 1). ${ }^{12,13}$ Those with GFR $\geq 60 \mathrm{~mL} / \mathrm{min} / 1.73 \mathrm{~m}^{2}$ (Stage 1-2) are considered to have CKD if they presented with kidney damage as defined by pathological abnormalities or markers of

P Sharma, BPharm, MSc, research fellow, G Prescott, BSc, MSc, $P h D, C S t a t$, senior lecturer in medical statistics, A MacLeod, MRCP, MD, professor of medicine and pharmacology, W Cairns Smith, $P h D, M D, M R C P, F F P H$, clinical professor of public health, C Black, BSc, MSc, MRCP, FFPH, senior clinical lecturer; G Scotland, BSc, MSc, research fellow; P McNamee, BA, MSc, $P h D$, senior research fellow, Health Economics Research Unit, University of Aberdeen, Aberdeen; K McCullough, MRCP, specialist registrar in nephrology, $N$ Fluck, $M R C P, M D$, consultant nephrologist, Aberdeen Royal Infirmary Renal Unit, NHS Grampian, Aberdeen.

Address for correspondence

Mrs Pawana Sharma, University of Aberdeen, Health Service Research Unit, Foresterhill, Health Sciences Building (second floor), Aberdeen, AB25 2ZD.

E-mail: p.sharma@abdn.ac.uk

Submitted: 9 November 2009; Editor's response: 11 January 2010; final acceptance: 11 March 2010.

@British Journal of General Practice

This is the full-length article of an abridged version published in print. Cite this article as: Br J Gen Pract 2010; DOI: 10.3399/bjgp10X502173. 
damage. In the UK, and elsewhere, this new definition has been accompanied by changes to improve the consistency of laboratory reporting, making it easier for clinicians to recognise impairment in kidney function. ${ }^{14}$ The addition of CKD management to the Quality and Outcomes Framework (QOF) in 2006 encouraged GPs who were responsible for the care of the majority of people with CKD to identify those with GFR $<60 \mathrm{~mL} / \mathrm{min} / 1.73 \mathrm{~m}^{2}$ (stage-3 CKD or worse) and record them on a practice register. Proactive management of blood pressure and use of angiotensin converting enzyme (ACE) inhibitors or angiotensin receptor blockers is also supported in the QOF and clinical guidelines. ${ }^{15,16}$ Internationally, similar opportunistic detection has been implemented and some countries or communities have introduced screening of groups who are at high risk of developing CKD. ${ }^{17,18}$

Stage-3 CKD is the first stage that can be identified from a blood test alone, and accounts for the vast majority of people now being detected and labelled with CKD on general practice disease registers. In every 10000 adult patients in primary care, an estimated 144 new patients will be detected each year with stage-3 CKD, as compared with three in stage 4 and 0.3 in stage $5 .{ }^{19}$ Stage-3 CKD also represents those people who would previously have gone unnoticed clinically, people who reflect a very different population than those diagnosed as having CKD and attending nephrology clinics in the past. In stages 4 and 5 , the clinical significance of CKD is well understood, with many individuals experiencing symptoms and complications (hypertension, anaemia, undernutrition, renal bone disease, and metabolic acidosis) as well as an increased risk of cardiovascular disease (CVD), all-cause mortality and end-stage renal disease (ESRD) requiring renal replacement therapy (RRT). ${ }^{14,15}$ In stage 3 , the clinical implications for the future health of the patient are less clear. ${ }^{20,21}$

In order to support patients, plan services, evaluate cost-effectiveness and develop policies, it is critical that the natural history of stage-3 CKD is understood. This article systematically reviews the natural history of stage-3 CKD in terms of mortality and renal outcomes.

\section{METHOD}

\section{Search strategy}

A systematic review of the published literature was conducted, searching the MEDLINE and Embase databases for studies dating from 1998 to February 2009. A combination of medical subject headings and text terms were used for 'chronic kidney disease' and 'natural history' (Table 2). A manual search of reference lists from included studies was carried out.

\section{How this fits in}

Chronic kidney disease (CKD) has now been recognised as a major healthcare challenge. The natural history of advanced stages of CKD have been widely reported but less is known about the stage 3 CKD. Stage 3 CKD is the first stage that is identifiable from a blood test alone and accounts for the majority of people on primary care CKD registers. This systematic literature review studied the natural history of stage $3 \mathrm{CKD}$. It found that mortality was consistently higher and cardiovascular disease was common compared to those without CKD, particularly for those with stage 3B CKD. Risk of progression to ESRD and dialysis was a substantially less frequent outcome.

Searches were restricted to English language.

\section{Inclusion/exclusion criteria}

Systematic review, meta-analysis, or follow-up study (prospective or retrospective) of people with CKD that included adults ( $\geq 18$ years) with stage-3 CKD (GFR $30-59 \mathrm{~mL} / \mathrm{min} / 1.73 \mathrm{~m}^{2}$ ) were considered eligible. Studies were restricted to non-trial study designs. Where a study also included participants in other stages of CKD, it was required that outcome data were presented separately for stage 3 . Studies were required to have a minimum of 2 years' follow-up. Studies with fewer than 100 subjects were excluded. Studies of single specific renal diagnoses or those including only pregnant participants were also excluded.

The primary outcome of interest was all-cause mortality. Secondary outcomes included: cardiovascular morbidity and mortality, and renal outcomes (CKD progression, ESRD or RRT). CKD progression was measured by rate of decline of estimated glomerular filtration rate (eGFR) or creatinine clearance, rise in serum creatinine, or transition through progressive stages of CKD.

\section{Study identification}

Two authors independently screened all titles and abstracts to identify potentially relevant studies. Full

\section{Table 1. Kidney Disease Outcomes Quality Initiative definition of chronic kidney disease (modified by the UK Renal Consensus conference to split stage 3 into two subgroups)..$^{12,13}$}

\begin{tabular}{ll} 
CKD stage & Definition (chronicity defined by presence of abnormality for $\geq 3$ months) \\
\hline Stage 1 & Kidney damage with normal or raised GFR $\left(\geq 90 \mathrm{~mL} / \mathrm{min} / 1.73 \mathrm{~m}^{2}\right)$ \\
\hline Stage 2 & Kidney damage with mildly impaired GFR $\left(60-89 \mathrm{~mL} / \mathrm{min} / 1.73 \mathrm{~m}^{2}\right)$ \\
\hline Stage 3A & Moderately impaired GFR $\left(45-59 \mathrm{~mL} / \mathrm{min} / 1.73 \mathrm{~m}^{2}\right)$ \\
\hline Stage 3B & Moderately impaired GFR $\left(30-44 \mathrm{~mL} / \mathrm{min} / 1.73 \mathrm{~m}^{2}\right)$ \\
\hline Stage 4 & Severely impaired GFR $\left(15-29 \mathrm{~mL} / \mathrm{min} / 1.73 \mathrm{~m}^{2}\right)$ \\
\hline Stage 5 & End-stage renal failure or GFR $<15 \mathrm{~mL} / \mathrm{min} / 1.73 \mathrm{~m}^{2}$ \\
\hline
\end{tabular}

Kidney damage is defined as pathologic abnormalities or markers of damage, including abnormalities in blood or urine tests or imaging studies. CKD = chronic kidney disease. GFR $=$ glomerular filtration rate 
Table 2. Example search strategy for MEDLINE (modified for Embase).

\begin{tabular}{|c|c|}
\hline Search & Search term \\
\hline 1 & Exp *Kidney Failure, Chronic/ \\
\hline 2 & (Renal or kidney or nephropath\$ or nephrolog\$).tw. \\
\hline 3 & CKD.tw. \\
\hline 4 & Exp *Natural History/ \\
\hline 5 & Exp Disease Progression/ \\
\hline 6 & Natural course.tw. \\
\hline 7 & Disease course.tw. \\
\hline 8 & $\begin{array}{l}\text { (Cohort or follow-up or follow-up or longitudinal or prospective or } \\
\text { screening or cross sectional or cross-sectional).tw. }\end{array}$ \\
\hline 9 & Population-based stud\$.tw. \\
\hline 10 & Exp Mass Screening/ \\
\hline 11 & Exp cohort studies/ or exp cross-sectional studies/ \\
\hline 12 & Exp "review"/ \\
\hline 13 & Mass screen\$.tw. \\
\hline 14 & Review.ti. \\
\hline 15 & 1 or 2 or 3 \\
\hline 16 & 4 or 5 or 6 or 7 \\
\hline 17 & 8 or 9 or 10 or 11 or 12 or 13 or 14 \\
\hline 18 & 15 and 16 and 17 \\
\hline 19 & Limit 18 to (English language and humans) \\
\hline
\end{tabular}

articles were retrieved in cases of disagreement. All the full articles were assessed against the inclusion and exclusion criteria by two authors. All disagreements were resolved by discussion and there was no need to seek the opinion of a third reviewer. Only those studies presenting relevant outcomes by stage-3 CKD were retained for data extraction and quality assessment.

\section{Table 3. Quality and judgement criteria.}

\begin{tabular}{ll} 
Criteria & Details \\
\hline 1. Sample selection & $\begin{array}{l}\text { Representativeness of the cohort for that community } \\
\text { Study population adequately defined } \\
\text { Information recorded prospectively } \\
\text { Ascertainment of sample described } \\
\text { Assessment of outcome described }\end{array}$ \\
\hline 2. Follow-up & $\begin{array}{l}\text { Losses to follow-up less than 10\% } \\
\text { Reason for loss to follow-up given } \\
\text { Characteristics of patients lost to follow-up described }\end{array}$ \\
\hline $\begin{array}{l}\text { 3. Other biases } \\
\text { D. Chronicity }\end{array}$ & $\begin{array}{l}\text { Design-specific sources of bias mentioned } \\
\text { Design-specific bias corrected }\end{array}$ \\
\hline $\begin{array}{l}\text { CKD defined to be chronic ( } \geq 3 \text { months) } \\
\text { renal impairment }\end{array}$ & $\begin{array}{l}\text { Differences in assays over time or between laboratories } \\
\text { accounted for }\end{array}$ \\
\hline $\begin{array}{l}\text { Quality judgement } \\
\text { Excellent }\end{array}$ & $\begin{array}{l}\text { Meeting all criteria (1-5) listed above } \\
\text { Good }\end{array}$ \\
$\begin{array}{l}\text { Moderate } \\
\text { Poor }\end{array}$ & $\begin{array}{l}\text { Meeting any three or four criteria out of the five criteria listed } \\
\text { Meeting less than two criteria of the five criteria listed }\end{array}$ \\
\hline CKD = chronic kidney disease.
\end{tabular}

\section{Data extraction and quality assessment}

One author extracted data and assessed the quality of each study using a specifically designed and piloted data-extraction form. A second researcher checked the extracted data for accuracy and disagreements were resolved by a third reviewer. Quality was assessed as described in Table 3. Studies were not excluded based on quality.

Quality assessment included generic quality criteria adapted from various methodological quality assessment tools, ${ }^{22-26}$ and CKD-specific quality criteria adapted from a systematic review of the prevalence of CKD. ${ }^{7}$ Generic quality issues included sample selection, follow-up, and bias. Specific quality criteria considered the definition of chronicity of CKD and the standardisation of the measure of renal function impairment. It was necessary to establish chronicity in order to exclude acute renal impairment and testing errors and, thus, reduce classification bias. Good-quality studies should use reliable, validated and less-biased assay techniques (modern compensated assays, enzymic assays, assays traceable to gold standard isotope dilution mass spectrometry) to minimise measurement bias.

\section{Synthesis of results}

The results were tabulated, grouped by study type, and reported narratively. Relative risk estimates (hazard ratios [HRs] and standardised mortality ratios) were converted to natural logs (In), and standard deviations estimated to allow graphical presentation using Review Manager software (Version 5). Due to the variability in the reporting of outcomes, data were not pooled in a meta-analysis.

\section{RESULTS}

\section{Study selection}

Out of 3453 references identified and screened, 118 full papers were retrieved; 17 papers from 13 studies met the inclusion criteria and were critically appraised (Figure 1). Hallan included three papers, ${ }^{27-29}$ Keith included two papers, ${ }^{30,31}$ and Eriksen included two papers. ${ }^{32,33}$ The first study in each is the primary reference and has been quoted throughout. No systematic reviews of the natural history of stage3 CKD were identified.

\section{Study characteristics}

A summary of the characteristics of the included studies is presented in Table 4. There were two methodological groups of studies:

- Clinical populations ( $n=$ nine studies): studies based on participants recruited from a clinical population (those from clinical record databases, laboratories, primary care, or clinical settings). ${ }^{31,32,34-40}$ 
- General populations ( $n=$ four studies): studies that were based on participants recruited from a general population (representing people in the community and identified through screening programmes). ${ }^{27,41-43}$

All but one study, ${ }^{32}$ reported findings for other CKD stages. The results of the participants with stage-3 CKD have been focused on only.

A total of 728328 people with stage-3 CKD were included; they accounted for between $4.5 \%{ }^{27}$ and $100 \%{ }^{32}$ of study cohorts. Follow-up varied from 2 years to 16 years. Most of the studies used the Modification of Diet in Renal Disease equation for GFR estimation, but one used the Cockroft and Gault equation..$^{35}$

Most studies (five) were from the US, with two each from Norway and Taiwan, and one each from the UK, the Netherlands, Canada, and Japan.

\section{Quality of included studies}

The quality assessment of included studies is shown in Table 5. None of the studies fulfilled all the quality criteria, however most (nine) were rated as 'good' quality; only one of the studies ${ }^{35}$ was graded as 'poor'. Six studies established the chronicity of reduced eGFR.

\section{Evidence of mortality}

Studies reported two types of mortality results for stage-3 CKD:

- the rate of mortality (number of deaths in a group per unit of time); and

- the risk of mortality (number of deaths compared with another group).

Among the nine studies reporting all-cause mortality, only one was a general population-based cohort, ${ }^{43}$ the other eight included clinical populations. . $^{30,32,34-37,39,40}$ Two studies reported CVD morbidity $^{36,41}$ and three CVD mortality. ${ }^{27,34,43}$ Detailed results of all-cause mortality, and CVD morbidity and mortality are given in Table 6 and Figure 2.

Rates of all-cause mortality, and CVD morbidity and mortality. In the six studies reporting mortality rates, ${ }^{30,32,34-36,39}$ estimates varied substantially but, where reported, mortality was consistently higher in those who had stage-3 CKD compared with those who did not have CKD. Chiu et $a^{34}$ reported the lowest cumulative mortality rate of $6 \%$ during 3 years' follow-up (2.1 per 100 person-years). The highest was reported by Eriksen and Ingebretsen ${ }^{32}$ with a mortality rate of $32 \%$ at 5 years and $51 \%$ at 10 years. The mortality rate was substantially higher

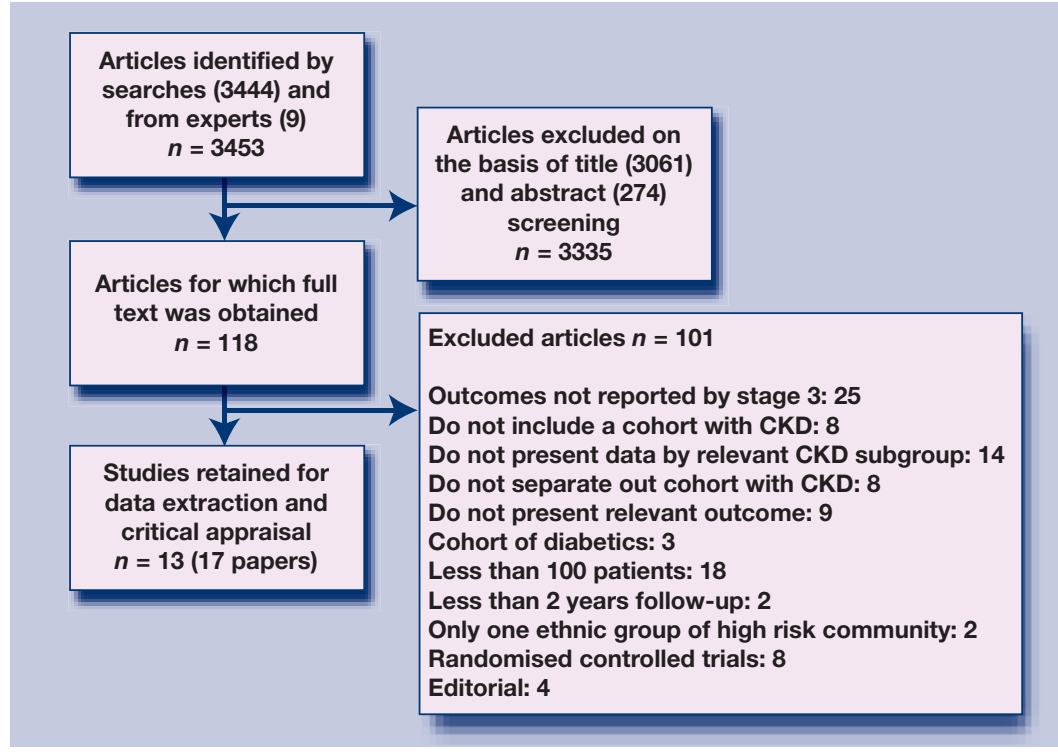

in stage 3B (4.8 deaths per 100 person-years) compared with stage $3 \mathrm{~A}$ (1.1 deaths per 100 personFigure 1. Summary of study selection. years).$^{36}$ Stratified annual mortality rates increased with age and eGFR. O'Hare et al ${ }^{39}$ reported that the mortality rate in the youngest group of patients (aged 18-44 years) with eGFR $50-59 \mathrm{~mL} / \mathrm{min} / 1.73 \mathrm{~m}^{2}$ was as low as $0.8 \%$ per year but increased to $14.7 \%$ in patients (85-100 years old) with eGFR $30-39 \mathrm{~mL} / \mathrm{min} / 1.73 \mathrm{~m}^{2}$.

CVD mortality and events varied, but again was consistently higher in those who had stage-3 CKD as compared to those with no CKD. In a clinical population study, $2 \%$ at 3 years were reported to have CVD deaths. ${ }^{34}$ In general population studies, CVD death rates varied from $4 \%$ at 13 years ${ }^{43}$ to $21 \%$ at 10 years..$^{27} \mathrm{CVD}$ mortality rates were higher in stage 3B (7.4 per 100 person-years, ${ }^{27} 8 \%$ at 13 years $^{43}$ ) as compared to stage 3A (3.5 per 100 person-years, ${ }^{27} 3 \%$ at 13 years ${ }^{43}$ ).

CVD event rates also varied from 2.1 per 100 person-years ${ }^{41}$ to 11.3 per 100 person-years. ${ }^{36}$ CVD event rates more than trebled from 3.7 per 100 person-years at stage $3 \mathrm{~A}$ to 11.3 per 100 personyears at stage $3 \mathrm{~B}^{36}$

Risk of all-cause mortality, and CVD morbidity and mortality versus no CKD. Four studies reported the relative risk of mortality for stage-3 CKD as compared with those without CKD. ${ }^{32,36,39,43} \mathrm{~A}$ small increase in the risk of mortality (HR 1.2-1.8), after adjustment for differences between the comparison groups in age, sex, and comorbidities, was observed for those people with stage-3 CKD compared with those with eGFR $\quad 260 \mathrm{~mL} / \mathrm{min} / 1.73 \mathrm{~m}^{2(36)}$ and eGFR $60-89 \mathrm{~mL} / \mathrm{min} / 1.73 \mathrm{~m}^{2}$ without proteinuria..$^{43}$ Eriksen and Ingebretsen ${ }^{32}$ reported an increase in risk of allcause mortality with an $\mathrm{HR}$ of $1.3(95 \% \mathrm{Cl}=1.1$ to 
Table 4. Characteristics of included studies.

\begin{tabular}{|c|c|c|c|c|c|c|c|c|c|}
\hline \multirow[b]{2}{*}{ Study } & \multirow[b]{2}{*}{$\begin{array}{l}\text { Cohort } \\
\text { ascertainment }\end{array}$} & \multirow{2}{*}{$\begin{array}{l}\text { Minimum } \\
\text { follow-up, } \\
\text { years }\end{array}$} & \multicolumn{2}{|c|}{ Participants, $n$} & \multicolumn{2}{|c|}{$\begin{array}{c}\text { Mean age } \\
\text { of participants, years }\end{array}$} & \multicolumn{2}{|c|}{$\begin{array}{c}\text { Male } \\
\text { participants (\%) }\end{array}$} & \multirow{2}{*}{$\begin{array}{c}\text { Comorbidities } \\
\text { stage } 3 \\
\text { CKD only (\%) }\end{array}$} \\
\hline & & & All & $\begin{array}{c}\text { Stage } 3 \text { CKD } \\
\text { (\% of total) }\end{array}$ & All & $\begin{array}{c}\text { Stage } 3 \\
\text { CKD }\end{array}$ & All & $\begin{array}{c}\text { Stage } 3 \\
\text { CKD }\end{array}$ & \\
\hline \multicolumn{10}{|c|}{ Clinical population-based cohort } \\
\hline $\begin{array}{l}\text { Chiu et } a^{/ 34} \\
\text { Taiwan, } \\
2008\end{array}$ & $\begin{array}{l}\text { Referrals to } \\
\text { nephrology } \\
\text { outpatient clinic }\end{array}$ & 3 & 433 & $184(42.5)$ & 65.6 & 65.7 & 61.7 & $\begin{array}{c}74.5 \\
\text { HBP: } 6.0 \\
\text { CVD: } 27.2 \\
\text { P: } 70.6\end{array}$ & DM: 30.4 \\
\hline $\begin{array}{l}\text { Djamali et } a^{\beta 5} \\
\text { US, } 2003\end{array}$ & $\begin{array}{l}\text { Hospital inpatients } \\
\text { and outpatients } \\
\text { with creatinine } \\
>1.3 \mathrm{mg} / \mathrm{dL}\end{array}$ & 16 & 1762 & $403(46.0)$ & 54 & 56 & 60 & 54 & DM: 43 \\
\hline $\begin{array}{l}\text { Eriksen and } \\
\text { Ingebretsen } \\
\text { Norway, } 2006 \\
\text { Additional } \\
\text { publication }^{33}\end{array}$ & $\begin{array}{l}\text { Hospital } \\
\text { laboratory } \\
\text { database }\end{array}$ & 10 & 3047 & $3047(100)$ & $75^{\mathrm{a}}$ & 75 & 30 & 30 & NR \\
\hline $\begin{array}{l}\text { Go et a/36 US, } \\
2004\end{array}$ & $\begin{array}{l}\text { Hospital } \\
\text { laboratory } \\
\text { database and } \\
\text { renal registry }\end{array}$ & 4 & 1120295 & $\begin{array}{c}\text { 3: } 187701(16.8) \\
\text { 3A: } 153426(13.7) \\
\text { 3B: } 34275(3.0)\end{array}$ & 52.2 & $\begin{array}{l}\text { 3A: } 65.4 \\
\text { 3B: } 71.2\end{array}$ & 45.4 & $\begin{array}{l}3 A: 39.3 \\
\text { 3B: } 38.4\end{array}$ & $\begin{array}{c}\text { DM 3A: } 12.3 \\
\text { 3B: } 19.6 \\
\text { CVD 3A: } 13.2 \\
\text { 3B: } 20.6 \\
\text { P 3A:8.9 } \\
\text { 3B: } 17.7 \\
\end{array}$ \\
\hline $\begin{array}{l}\text { Hemmelgarn } \\
\text { et } a^{\beta 7} \text { Canada, } \\
2006\end{array}$ & $\begin{array}{l}\text { Regional } \\
\text { laboratory } \\
\text { database }\end{array}$ & $\begin{array}{c}\text { Median } 2 \\
(\text { IQR 1.9-2.2) }\end{array}$ & 10184 & $3191(31.0)$ & range: $75-78$ & 77.8 & $45.1-37.5$ & 37.5 & DM: 19.8 \\
\hline $\begin{array}{l}\text { Keith et } a^{30} \\
\text { US, } 2004 \\
\text { Additional } \\
\text { publication } \\
\end{array}$ & $\begin{array}{l}\text { Health } \\
\text { insurance claims } \\
\text { database }\end{array}$ & 5.5 & 27998 & $1741(6.2)$ & range: $61-74$ & 71.6 & NR & 37.8 & $\begin{array}{l}{ }^{\circ} \mathrm{DM}: 15.8 \\
{ }^{\mathrm{b}} \mathrm{CVD}: 13.1 \\
{ }^{\mathrm{b}} \mathrm{HBP}: 37.4\end{array}$ \\
\hline $\begin{array}{l}\text { Khatami et a/38 } \\
\text { UK, } 2007\end{array}$ & $\begin{array}{l}\text { Hospital } \\
\text { database }\end{array}$ & 4 & 8160 & $520(6.4)$ & $\begin{array}{l}\text { Male: } 63.5^{\mathrm{a}} \\
\text { Female: } 67^{\mathrm{a}}\end{array}$ & NR & 58.7 & NR & $\begin{array}{l}{ }^{\mathrm{b}} \mathrm{DM}: 1.3 \\
{ }^{\mathrm{b}} \mathrm{CVD}: 0.4\end{array}$ \\
\hline $\begin{array}{l}\text { O'Hare et a/39 } \\
\text { US, } 2006\end{array}$ & $\begin{array}{l}\text { Veterans' health } \\
\text { insurance database } \\
\text { (128 centres) and } \\
\text { National ESRD regist }\end{array}$ & $\begin{array}{l}\text { Mean } 3.17 \\
\text { (SD 0.62) } \\
\text { stry }\end{array}$ & 2583911 & $476337(18.4)$ & 63.6 & NR & 95 & NR & $\begin{array}{l}{ }^{\circ} D M: 10-36 \\
{ }^{\circ} C V D: 6-58\end{array}$ \\
\hline $\begin{array}{l}\text { Orlando et } a l,{ }^{40} \\
\text { US, } 2007\end{array}$ & $\begin{array}{l}\text { Veterans' health } \\
\text { insurance } \\
\text { (single centre) }\end{array}$ & $\begin{array}{l}\text { Approx. } 5 \\
\text { (mean 3.5) }\end{array}$ & 1553 & $416(26.8)$ & 70 & NR & 100 & 100 & $\begin{array}{l}{ }^{\mathrm{b}} \mathrm{DM}: 52 \\
{ }^{\mathrm{b}} \mathrm{HBP}: 92 \\
{ }^{\circ} \mathrm{P}: 89\end{array}$ \\
\hline \multicolumn{10}{|c|}{ General population-based cohort } \\
\hline $\begin{array}{l}\text { Brantsma et a/41 } \\
\text { the Netherlands, } \\
2008\end{array}$ & $\begin{array}{l}\text { Health screening: } \\
\text { sample enriched } \\
\text { for those with } \\
\text { albuminuria }\end{array}$ & $\begin{array}{l}\text { Median } 7.5 \\
\text { (IQR: 6.9-7.8) }\end{array}$ & 8495 & $491(31.0)$ & 49.2 & 63.2 & 50 & 53.4 & $\begin{array}{c}\text { DM: } 5.9 \\
\text { HBP: } 46.3\end{array}$ \\
\hline $\begin{array}{l}\text { Hallan et } a^{27} \\
\text { Norway, } 2006 \\
\text { Additional } \\
\text { publications } \\
\end{array}$ & Health screening & 10.3 & 65604 & $\begin{array}{c}\text { 3: } 2973(4.5) \\
\text { 3A: } 2389(3.6) \\
\text { 3B: } 548(0.8)\end{array}$ & 49 & NR & 46.8 & $N^{b}$ & $\begin{array}{c}\text { DM: } 3 \\
\text { 'HBP: } 11.1 \\
{ }^{\circ} \mathrm{CVDD}: 7.9\end{array}$ \\
\hline $\begin{array}{l}\text { Imai et } a^{1 / 2} \\
\text { Japan, } 2008\end{array}$ & Health screening & 10 & 120727 & 3: 25715 (21.4) & range $40-79$ & NR & 32.7 & NR & $\begin{array}{l}\text { 'HBP: } 13.9 \\
\text { 'PP: } 1.7\end{array}$ \\
\hline $\begin{array}{l}\text { Wen et a/43 } \\
\text { Taiwan, } 2008\end{array}$ & Health screening & 13 & 462293 & $\begin{array}{c}\text { 3: } 25609(5.5) \\
\text { 3A: } 22597(4.9) \\
\text { 3B: } 3012(0.7)\end{array}$ & 41.8 & 61.9 & 49.8 & 53.4 & $\begin{array}{l}\text { DM: } 14.5 \\
\text { HBP: } 56.6 \\
\text { P: } 20.4\end{array}$ \\
\hline
\end{tabular}

$C K D=$ chronic kidney disease. $C V D=$ cardiovascular disease. $D M=$ diabetes mellitus. $E S R D=$ end-stage renal disease. $H B P=$ high blood pressure. $I Q R=$ interquartile range. $N R=$ not reported. $P=$ proteinuria. ${ }^{a}$ Median age in years. ${ }^{b}$ Comorbidities in total CKD participants.

1.4) for each $10 \mathrm{~mL} / \mathrm{min} / 1.73 \mathrm{~m}^{2}$ decrease in eGFR. Go et $a^{\beta 6}$ and Wen et $a l^{43}$ reported that the relative risk of mortality for stage $3 \mathrm{~B}$ was almost double that of stage 3A (Figure 2). 
Table 5. Quality assessment of included studies.

\begin{tabular}{|c|c|c|c|c|c|c|c|c|c|c|c|c|c|}
\hline \multirow[b]{2}{*}{ Quality criteria } & \multicolumn{13}{|c|}{ Study reference number } \\
\hline & 41 & 34 & 35 & 32 & 36 & 27 & 37 & 42 & 30 & 38 & 39 & 40 & 43 \\
\hline \multicolumn{14}{|l|}{ Sample selection } \\
\hline Representative of the community & Y & $\mathrm{Y}$ & $U$ & Y & Y & $\mathrm{Y}$ & Y & Y & $\mathrm{Y}$ & $\mathrm{U}$ & $\mathrm{Y}$ & $\mathrm{Y}$ & Y \\
\hline $\begin{array}{l}\text { Study population adequately } \\
\text { defined }\end{array}$ & $\mathrm{Y}$ & $\mathrm{Y}$ & $\mathrm{Y}$ & $\mathrm{Y}$ & $\mathrm{Y}$ & $\mathrm{Y}$ & $\mathrm{Y}$ & $\mathrm{Y}$ & $\mathrm{Y}$ & $\mathrm{U}$ & Y & $\mathrm{Y}$ & Y \\
\hline Information recorded prospectively & Y & $\mathrm{Y}$ & $\mathrm{Y}$ & Y & Y & Y & Y & Y & Y & Y & $\mathrm{Y}$ & $\mathrm{Y}$ & Y \\
\hline Ascertainment of sample described & $\mathrm{Y}$ & $\mathrm{Y}$ & $\mathrm{N}$ & Y & Y & $\mathrm{Y}$ & $\mathrm{Y}$ & $\mathrm{Y}$ & $\mathrm{Y}$ & $\mathrm{Y}$ & Y & Y & Y \\
\hline Assessment of outcome described & $\mathrm{Y}$ & $\mathrm{Y}$ & $\mathrm{N}$ & $\mathrm{Y}$ & $\mathrm{Y}$ & $\mathrm{Y}$ & $\mathrm{Y}$ & $\mathrm{Y}$ & $\mathrm{Y}$ & $\mathrm{Y}$ & $\mathrm{Y}$ & $\mathrm{Y}$ & $\mathrm{Y}$ \\
\hline \multicolumn{14}{|l|}{ Follow-up } \\
\hline Loss to follow-up $<10 \%$ & $\mathrm{~N}$ & $\mathrm{Y}$ & $\mathrm{N}$ & C & $\mathrm{N}$ & $\mathrm{C}$ & $\mathrm{C}$ & C & $\mathrm{C}$ & $\mathrm{C}$ & $U$ & $\mathrm{Y}$ & C \\
\hline Reason for loss to follow-up given & $\mathrm{N}$ & $\mathrm{N}$ & $\mathrm{Y}$ & $\mathrm{n} / \mathrm{a}$ & $\mathrm{Y}$ & $\mathrm{n} / \mathrm{a}$ & $\mathrm{n} / \mathrm{a}$ & $\mathrm{n} / \mathrm{a}$ & $\mathrm{n} / \mathrm{a}$ & $\mathrm{n} / \mathrm{a}$ & - & $\mathrm{N}$ & $\mathrm{n} / \mathrm{a}$ \\
\hline $\begin{array}{l}\text { Characteristics of patient loss } \\
\text { to follow-up described }\end{array}$ & $\mathrm{Y}$ & $\mathrm{N}$ & $\mathrm{N}$ & $\mathrm{n} / \mathrm{a}$ & $\mathrm{Y}$ & $\mathrm{n} / \mathrm{a}$ & $\mathrm{n} / \mathrm{a}$ & $\mathrm{n} / \mathrm{a}$ & $\mathrm{n} / \mathrm{a}$ & $\mathrm{n} / \mathrm{a}$ & - & $\mathrm{N}$ & $\mathrm{n} / \mathrm{a}$ \\
\hline \multicolumn{14}{|l|}{ Other biases } \\
\hline $\begin{array}{l}\text { Design-specific sources of bias } \\
\text { mentioned }\end{array}$ & $\mathrm{Y}$ & Y & Y & $\mathrm{N}$ & $\mathrm{N}$ & Y & Y & Y & $\mathrm{Y}$ & $\mathrm{N}$ & Y & $\mathrm{Y}$ & Y \\
\hline Design-specific bias corrected & $\mathrm{Y}$ & $\mathrm{Y}$ & $\mathrm{N}$ & $\mathrm{Y}$ & $\mathrm{N}$ & $\mathrm{Y}$ & $\mathrm{Y}$ & $\mathrm{Y}$ & $\mathrm{Y}$ & $\mathrm{N}$ & $\mathrm{Y}$ & $\mathrm{Y}$ & Y \\
\hline \multicolumn{14}{|l|}{ Chronicity } \\
\hline $\begin{array}{l}\text { CKD defined to be chronic } \\
\text { ( } \geq 3 \text { months) }\end{array}$ & $\mathrm{N}$ & Y & Y & Y & Y & $\mathrm{N}$ & $\mathrm{N}$ & $\mathrm{N}$ & $\mathrm{Y}$ & $U$ & $N$ & Y & $\mathrm{N}$ \\
\hline \multicolumn{14}{|l|}{ Measurement of renal impairment } \\
\hline $\begin{array}{l}\text { Difference in assays over time or } \\
\text { between labs accounted for }\end{array}$ & $\mathrm{N}$ & $\mathrm{N}$ & $\mathrm{N}$ & $U$ & $\mathrm{Y}$ & $\mathrm{Y}$ & Y & $\mathrm{Y}$ & $U$ & $Y$ & $N$ & $\mathrm{~N}$ & $Y$ \\
\hline Overall quality & $M$ & $\mathrm{G}$ & $P$ & $\mathrm{G}$ & $\mathrm{G}$ & $\mathrm{G}$ & $\mathrm{G}$ & $\mathrm{G}$ & $\mathrm{G}$ & $\mathrm{M}$ & $M$ & $G$ & $\mathrm{G}$ \\
\hline
\end{tabular}

O'Hare et $a^{39}$ estimated the relative risk of mortality stratified by age and level of renal function across stage 3 (eGFR only reported by following categories: $50-59, \quad 40-49$ and $30-39 \mathrm{~mL} / \mathrm{min} / 1.73 \mathrm{~m}^{2}$ ), as compared with eGFR $\geq 60 \mathrm{~mL} / \mathrm{min} / 1.73 \mathrm{~m}^{2}$. For those with eGFR $50-59 \mathrm{~mL} / \mathrm{min} / 1.73 \mathrm{~m}^{2}$, older age groups (65-74 years) were found to be at no increased risk of all-cause mortality ( $\mathrm{HR} 1.02,95 \% \mathrm{Cl}=1.0$ to 1.1$)$, whereas in younger patients (aged 18-44 years) the $\mathrm{HR}$ was $1.6(95 \% \mathrm{Cl}=1.3$ to 1.9$)$. For those with a lower level of renal function (eGFR $40-49$ and $30-39 \mathrm{~mL} / \mathrm{min} / 1.73 \mathrm{~m}^{2}$ ), associated relative risk decreased with increasing age. For example, risk of all-cause mortality for those with eGFR $40-49 \mathrm{~mL} / \mathrm{min} / 1.73 \mathrm{~m}^{2}$ decreased from HR 1.9 (95\% $\mathrm{Cl}=1.4$ to 2.7 in those aged $18-44$ years) to HR 1.4 $(95 \% \mathrm{Cl}=1.3$ to 1.4 in those aged $65-74$ years). Similarly, for those with eGFR $30-39 \mathrm{~mL} / \mathrm{min} / 1.73 \mathrm{~m}^{2}$, risk decreased from $\mathrm{HR} 3.6(95 \% \mathrm{Cl}=2.5$ to 5.1 in those aged $18-44$ years $)$ to $\mathrm{HR} 1.8(95 \% \mathrm{Cl}=1.8$ to 1.9 in those aged $65-74$ years).

Two studies reported risk of CVD events, ${ }^{36,41}$ while only one ${ }^{43}$ reported risk of CVD mortality. The risk of CVD events was increased in stage- 3 CKD, as compared with no CKD (stage-3 HR $1.3[95 \% \mathrm{Cl}=$ 1.0 to 1.7$]^{41}$ and stage-3A HR $1.4[95 \% \mathrm{Cl}=1.4$ to 1.5]). ${ }^{36}$ Stage $3 \mathrm{~B}$ had a $60 \%$ greater risk of CVD events than stage $3 A .^{36}$ Wen et $a^{43}$ reported an adjusted $\mathrm{HR}$ of $1.7(95 \% \mathrm{Cl}=1.5$ to 2.0$)$ for $\mathrm{CVD}$ deaths for those with stage-3A CKD (as compared with those with eGFR $60-89 \mathrm{~mL} / \mathrm{min} / 1.73 \mathrm{~m}^{2}$ without proteinurea), again with a higher risk in those with stage 3B (HR 3.3; $95 \% \mathrm{Cl}=2.7$ to 4.1$)^{43}$ (Figure 2).

\section{Evidence of renal outcomes}

Renal outcomes were reported by eight studies and included ESRD, RRT, and CKD progression (Table 7).

End-stage renal disease or renal replacement therapy. Four studies reported rates of ESRD or RRT for specified time periods. ${ }^{27,30,32,34}$ Cumulative incidence of renal failure at 5 years was $1.3-2 \%$ and $4 \%$ at 10 years for those with stage- 3 CKD. ${ }^{30,32}$ Chiu et al, ${ }^{34}$ studying patients referred to a nephrologist, reported an ESRD (defined as initiation of RRT) rate of 1.4 per 100 person-years. Hallan et al,,$^{27}$ in their general population study, reported a lower rate of ESRD for stage-3A CKD (0.04 per 100 person-years) than stage-3B CKD (0.2 per 100 person-years).

One study reported the risk of renal failure ${ }^{32}$ and one reported the risk of $\mathrm{ESRD}^{27}$ for those with stage3 CKD, as compared with no CKD. Eriksen and Ingebretsen ${ }^{32}$ reported an $\mathrm{HR}$ of $2.5(95 \% \mathrm{Cl}=1.9$ to 3.3) for each eGFR decrease of $10 \mathrm{~mL} / \mathrm{min} / 1.73 \mathrm{~m}^{2}$; a risk 5.3 times greater than the general population (standardised for age and sex). Hallan et $a^{27}$ estimated that the risk of progression to ESRD was $11.5(95 \% \mathrm{Cl}=6.6$ to 20.2$)$ for those with stage-3A 
Table 6. Summary of all-cause mortality, and CVD morbidity and mortality in stage-3 CKD.

\begin{tabular}{|c|c|c|c|c|}
\hline Study & Measures & All-cause mortality & CVD morbidity and mortality & Comments \\
\hline \multicolumn{5}{|c|}{ Clinical population-based cohort } \\
\hline Chiu et $a{ }^{34}$ & $\begin{array}{l}\mathrm{n} / \mathrm{N}: \\
\text { Rates: }\end{array}$ & $\begin{array}{l}11 / 184 \\
2.1 \text { deaths/100py } \\
6 \% \text { at } 3 \text { years }\end{array}$ & $\begin{array}{l}\text { CVD deaths } \\
3 / 184 \\
2 \% \text { at } 3 \text { years }\end{array}$ & \\
\hline Djamali et $a^{\beta 5}$ & $\begin{array}{l}\mathrm{n} / \mathrm{N}: \\
\text { Rates: }\end{array}$ & $\begin{array}{l}85 / 403(21 \%) \\
21 \% \text { at } 12.6 \text { years }\end{array}$ & $\begin{array}{l}N R \\
N R\end{array}$ & Adjusted for age and sex \\
\hline $\begin{array}{l}\text { Eriksen and } \\
\text { Ingebretsen }\end{array}$ & $\begin{array}{l}\mathrm{n} / \mathrm{N}: \\
\text { Rates: }\end{array}$ & $\begin{array}{l}959 / 3047(31.5 \%) \\
32 \% \text { at } 5 \text { years }(95 \% \mathrm{Cl}=30 \text { to } 34) \\
51 \% \text { at } 10 \text { years }(95 \% \mathrm{Cl}=48 \text { to } 55\end{array}$ & NR & NR \\
\hline Go et $a^{36}$ & $\begin{array}{l}\mathrm{n} / \mathrm{N}: \\
\text { Rates: }\end{array}$ & $\begin{array}{l}\text { Stage 3: 19371/187701 (10.3\%) } \\
\text { Stage 3A: } 11569 / 153426(7.5 \%) \\
\text { Stage 3B: } 7802 / 34275(22.8 \%) \\
\text { Stage 3A: } 1.1 \text { deaths/100py } \\
\text { Stage 3B: } 4.8 \text { deaths/100py }\end{array}$ & $\begin{array}{l}\text { CVD events }^{\mathrm{a}} \\
\text { Stage 3: 53270/187701 (28.4\%) } \\
\text { Stage 3A: 34690/153426 (22.6\%) } \\
\text { Stage 3B: } 18580 / 34275(54.2 \%) \\
\text { Stage 3A: 3.7/100pyc } \\
\text { Stage 3B: } 11.3 / 100 \mathrm{py}^{\mathrm{c}}\end{array}$ & Compared with those with eGFR $\geq 60$ : \\
\hline Hemmelgarn et $a^{177}$ & $\begin{array}{l}\mathrm{n} / \mathrm{N}: \\
\text { Rates: }\end{array}$ & $\begin{array}{l}\text { Stage 3B: } 192 / 3191(6.0 \%) \\
\text { Not calculable }^{d}\end{array}$ & $\begin{array}{l}\text { NR } \\
\text { NR }\end{array}$ & Proportions not reported for stage 3 or $3 \mathrm{~A}$ \\
\hline Keith et $a^{30}$ & $\begin{array}{l}\mathrm{n} / \mathrm{N}: \\
\text { Rates: }\end{array}$ & $\begin{array}{l}423 / 1741 \\
24 \% \text { at } 5 \text { years }\end{array}$ & $\begin{array}{l}N R \\
N R\end{array}$ & \\
\hline $\mathrm{O}^{\prime} \mathrm{Hare}^{39}$ & $\begin{array}{l}\mathrm{n} / \mathrm{N}: \\
\text { Rates: }\end{array}$ & $\begin{array}{l}\text { NR } \\
\text { Stratified by age group }\end{array}$ & $\begin{array}{l}\text { NR } \\
\text { NR }\end{array}$ & \\
\hline Orlando et $a l^{40}$ & $\begin{array}{l}\mathrm{n} / \mathrm{N}: \\
\text { Rates: }\end{array}$ & $\begin{array}{l}205 / 416 \\
49 \% \text { at } \sim 5 \text { years }^{\mathrm{e}}\end{array}$ & $\begin{array}{l}\text { NR } \\
\text { NR }\end{array}$ & \\
\hline General population-k & ased cohort & & & \\
\hline Brantsma et $a l^{41}$ & $\begin{array}{l}\mathrm{n} / \mathrm{N}: \\
\text { Rates: }\end{array}$ & $\begin{array}{l}\text { NR } \\
\text { NR }\end{array}$ & $\begin{array}{l}\text { CVD events } \\
\text { NR } \\
2.1 / 100 \text { py }\end{array}$ & $\begin{array}{l}\text { Compared with those without } \\
C K D=0.7 / 100 \text { py }\end{array}$ \\
\hline Hallan et $a^{27}$ & Rates: & NR & $\begin{array}{l}\text { CVD deaths } \\
\text { Stage 3: } 641 / 2973(21.6 \%) \\
\text { Stage 3A: } 456 / 2389(19.1 \%) \\
\text { Stage 3B: } 185 / 548(33.8 \%) \\
\text { Stage 3A: 3.5/100py } \\
\text { Stage 3B: 7.4/100py }\end{array}$ & Compared with eGFR $\geq 60=0.4 / 100 p y$ \\
\hline Wen et $a^{43}$ & Rates: & $\begin{array}{l}\text { Stage 3: } 3856 / 25609(15.1 \%) \\
\text { Stage 3A: } 2975 / 22597(13.2 \%) \\
\text { Stage 3B: } 881 / 3012(29.2 \%) \\
\text { Stage 3: } 15 \% \text { at } 13 \text { years } \\
\text { Stage 3A: } 14 \% \text { at } 13 \text { years } \\
\text { Stage 3B: } 29 \% \text { at } 13 \text { years }\end{array}$ & $\begin{array}{l}\text { CVD deaths } \\
\text { Stage 3: } 1032 / 25609(4.0 \%) \\
\text { Stage 3A: } 778 / 22597(3.4 \%) \\
\text { Stage 3B: } 254 / 3012(8.4 \%) \\
\text { Stage 3: } 4 \% \text { at } 13 \text { years } \\
\text { Stage 3A: } 3 \% \text { at } 13 \text { years } \\
\text { Stage 3B: } 8 \% \text { at } 13 \text { years }\end{array}$ & \\
\hline
\end{tabular}

${ }^{a}$ An individual can experience more than one event. ${ }^{\circ} 0.76 / 100 p y .{ }^{\circ} 2.11 / 100 p y$; standardised for age. ${ }^{\circ}$ Only median follow-up time reported. ${ }^{e}$ Proportions who died while in stage 3. CKD = chronic kidney disease. CVD = cardiovascular disease. eGFR = estimated glomerular filtration rate expressed as $\mathrm{mL} / \mathrm{min}^{\prime} 1.73 \mathrm{~m}{ }^{2}$ $n=$ number of events. $N=$ total number of patients with stage-3 $C K D$. $N R=$ not reported. $p y=$ person-years.

CKD and $52.6(95 \% \mathrm{Cl}=29.6$ to 93.4$)$ for those with stage-3B CKD, as compared with those without CKD (eGFR $\geq 60 \mathrm{~mL} / \mathrm{min} / 1.73 \mathrm{~m}^{2}$ ).

$C K D$ progression. Rate of progression, as mean GFR or creatinine clearance decline, was reported by four studies $^{32,34,35,42}$ and ranged from 1.03 to 5.4 $\mathrm{mL} / \mathrm{min} / 1.73 \mathrm{~m}^{2} /$ year. Hemmelgarn et ${ }^{1 / 37}$ reported greater decline in eGFR per year (adjusted for age) for male participants $\left(1.9 \mathrm{~mL} / \mathrm{min} / 1.73 \mathrm{~m}^{2} /\right.$ year; $95 \%$ $\mathrm{Cl}=1.5$ to 2.3$)$ versus females $\left(1.1 \mathrm{~mL} / \mathrm{min} / 1.73 \mathrm{~m}^{2}\right.$; $95 \% \mathrm{Cl}=0.8$ to 1.4 ).

Imai et $a^{/ 2}$ graphically presented the annual rate of eGFR decline stratified by different age groups (40-49, 50-59, 60-69 and 70-79 years), sex and baseline eGFR (50-59, 40-49 and $\left.30-39 \mathrm{~mL} / \mathrm{min} / 1.73 \mathrm{~m}^{2}\right)$. In general, it was observed that the rate of decline increased as the level of 


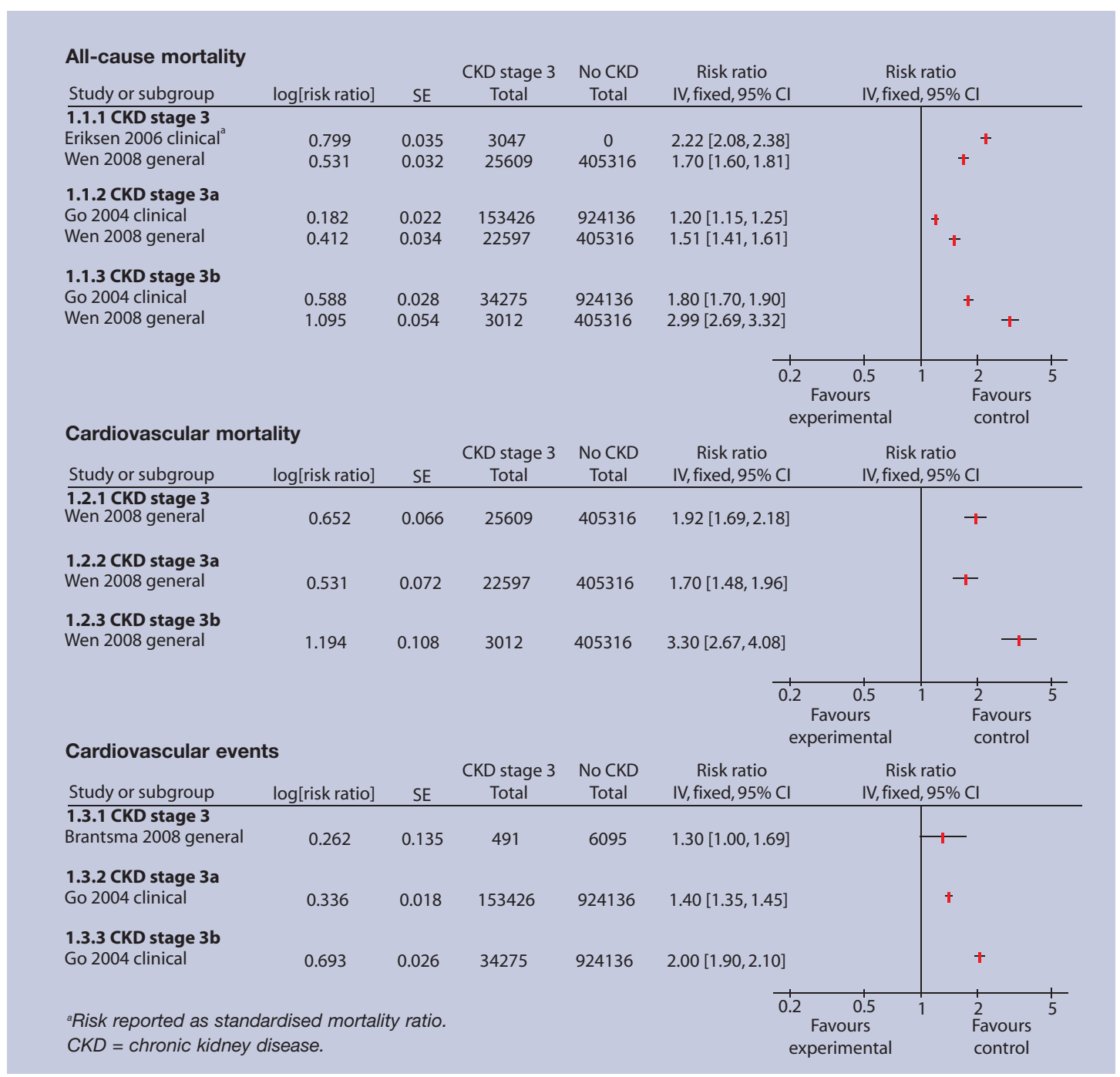

Figure 2. Relative risk of all-cause mortality, cardiovascular disease mortality, and cardiovascular disease events. kidney function decreased in both males and females and across all age groups (except in males aged 50-59 years). The highest rate of decline (mean 3.3; standard error of mean $0.7 \mathrm{~mL} / \mathrm{min} / 1.73 \mathrm{~m}^{2} /$ year) was observed in the youngest male group (aged 40-49 years) with an eGFR of $30-39 \mathrm{~mL} / \mathrm{min} / 1.73 \mathrm{~m}^{2}$.

Eriksen and Ingebretsen's study, ${ }^{32}$ which included only patients with stage-3 CKD, reported that only $6 \%$ had a mean eGFR decline greater than $5 \mathrm{~mL} / \mathrm{min} / 1.73 \mathrm{~m}^{2}$ and $27 \%$ experienced no decline in function. Khatami et a ${ }^{\beta 8}$ followed people with eGFR $<60 \mathrm{~mL} / \mathrm{min}$ for 4 years and reported that approximately $4 \%$ progressed to stage- 4 or stage- 5 CKD, 20\% regressed to stage-2 CKD and $76 \%$ were stable. Orlando et $a^{1 / 0}$ reported that only $17 \%$ of those patients at stage 3 progressed to the next stage during at least 5 years follow-up.

\section{DISCUSSION}

\section{Summary of evidence}

Despite the substantial focus clinically, and at a policy level, on the management of mild to moderate or 'early' CKD, this is, to the best of our knowledge, the first systematic review of the natural history of stage-3 CKD.

The absolute rate of death among those with stage-3 CKD varied between studies but was as high as $51 \%$ at 10 years and was markedly higher in stage $3 \mathrm{~B}$ compared with stage $3 \mathrm{~A}$. Compared with those with no CKD, mortality was consistently higher after adjustment of age, sex, and comorbidities. However, the increase was small for those with stage-3A disease and greater in stage 3B. As age increased, the additional risk of death attributable to low eGFR decreased. This has two important implications in general practice: in older age groups, a large number of deaths may occur in patients with CKD; however, because risk of death from other causes is also increased, for the individual patient, the additional diagnosis of CKD has little impact on risk of death.

ESRD was a rare outcome (4\% after 10 years follow-up, 0.04 per 100 person-years) but was greater in those with stage-3B CKD compared with 
Table 7. Summary of renal outcomes in stage-3 CKD.

\begin{tabular}{|c|c|c|c|c|}
\hline Study & Measures & ESRD or RRT & CKD progression & Comments \\
\hline \multicolumn{5}{|c|}{ Clinical population-based study } \\
\hline \multirow[t]{4}{*}{ Chiu et $a l^{\beta 4}$} & & ESRD & & ESRD defined as initiation of RRT \\
\hline & $\mathrm{n} / \mathrm{N}:$ & $7 / 184(3.8 \%)$ & NR & \\
\hline & Rates: & 1.4/100py & Mean GFR decline: & \\
\hline & & $4 \%$ at 3 years & 2.2 (SE 0.3) $\mathrm{mL} / \mathrm{min} / 1.73 \mathrm{~m}^{2} /$ year & \\
\hline \multirow[t]{2}{*}{ Djamali et $a^{35}$} & $\mathrm{n} / \mathrm{N}:$ & NR & NR & \\
\hline & Rates: & NR & $\begin{array}{l}\text { Mean } \mathrm{CrCl} \text { decline: } \\
5.4(\mathrm{SD} 7.4) \mathrm{mL} / \mathrm{min} / \text { year }\end{array}$ & $\begin{array}{l}\text { Progression defined as mean rate of } \mathrm{CrCl} \\
\text { decline in } \mathrm{mL} / \mathrm{min} / \text { year }\end{array}$ \\
\hline \multirow[t]{6}{*}{$\begin{array}{l}\text { Eriksen and } \\
\text { Ingebretsen }^{32}\end{array}$} & & ESRD & & $\begin{array}{l}\text { ESRD defined as stage } 5 \text { CKD or } \\
\text { initiation of RRT }\end{array}$ \\
\hline & $\mathrm{n} / \mathrm{N}:$ & $62 / 3047(2.0 \%)$ & Proportion with eGFR decline & \\
\hline & & & $>0 \mathrm{~mL} / \mathrm{min} / 1.73 \mathrm{~m}^{2} /$ year: $73 \%$ & \\
\hline & & & $>5 \mathrm{~mL} / \mathrm{min} / 1.73 \mathrm{~m}^{2} /$ year: $6 \%$ & \\
\hline & Rates: & $2 \%$ at 5 years & mean eGFR decline: & \\
\hline & & $4 \%$ at 10 years & $1.03 \mathrm{~mL} / \mathrm{min} / 1.73 \mathrm{~m}^{2} /$ year & \\
\hline \multirow[t]{5}{*}{ Hemmelgarn et $a^{37}$} & $\mathrm{n} / \mathrm{N}:$ & NR & NR & \\
\hline & Rates: & NR & eGFR decline & Rates adjusted for age, sex, diabetes \\
\hline & & & $\left(\mathrm{mL} / \mathrm{min} / 1.73 \mathrm{~m}^{2} /\right.$ year $)$ & mellitus, and comorbidity score; the rates \\
\hline & & & $\mathrm{M}: 1.9(95 \% \mathrm{Cl}=1.5$ to 2.3$)$ & were for participants without diabetes \\
\hline & & & $\mathrm{F}: 1.1(95 \% \mathrm{Cl}=0.8$ to 1.4$)$ & mellitus \\
\hline \multirow[t]{4}{*}{ Keith et $a l^{31}$} & & RRT & & \\
\hline & $\mathrm{n} / \mathrm{N}:$ & 23/1741 (1.3\%) & NR & \\
\hline & Rates: & $1.3 \%$ at 5 years & & \\
\hline & & (transplant: $0.2 \%$; dialysis: $1.1 \%$ ) & NR & \\
\hline \multirow[t]{5}{*}{ Khatami et $a^{/ 38}$} & $\mathrm{n} / \mathrm{N}:$ & NR & Progression to stage $4 / 5: 22 / 520$ & Approximate proportions reported for \\
\hline & Rates: & NR & Progression to stage $4 / 5: 4 \%$ at & regression and no progression \\
\hline & & & 4 years & \\
\hline & & & $\begin{array}{l}\text { Regression to stage } 2: \sim 20 \% \\
\text { at } 4 \text { years }\end{array}$ & \\
\hline & & & No progression: $~ 76 \%$ at 4 years & \\
\hline \multirow[t]{2}{*}{ Orlando et $a 4^{40}$} & $\mathrm{n} / \mathrm{N}:$ & NR & $70 / 416$ & CKD progression defined as progression \\
\hline & Rates: & NR & $17 \%$ at $\sim 5$ years & \\
\hline \multicolumn{5}{|c|}{ General population-based study } \\
\hline Hallan et $a^{27}$ & & ESRD & & \\
\hline \multirow[t]{5}{*}{ Hallan et $a l^{29}$} & $\mathrm{n} / \mathrm{N}:$ & Stage 3: 16/2973 (0.5\%) & & \\
\hline & & Stage 3A: 9/2389 (0.3\%) & & \\
\hline & & Stage 3B: $7 / 548$ (1.3\%) & NR & \\
\hline & Rates: & Stage 3A: 0.04/100py & & \\
\hline & & Stage 3B: 0.2/100py & NR & \\
\hline \multirow[t]{2}{*}{ Imai et $a^{/ 42}$} & $\mathrm{n} / \mathrm{N}:$ & NR & NR & \\
\hline & Rates: & NR & $\begin{array}{l}\text { Annual progression rate stratified } \\
\text { by age, sex and baseline eGFR }\end{array}$ & \\
\hline
\end{tabular}

$C K D=$ chronic kidney disease. $\mathrm{CrCl}=$ creatinine clearance. (e)GFR = (estimated) glomerular filtration rate. ESRD = end-stage renal disease; $F=$ female. $M=$ male. $n=$ number of events. $N=$ total number of patient with stage-3 CKD. NR = not reported. py = person-years. RRT = renal replacement therapy. $S D=$ standard deviation. SE = standard error.

those with stage-3A CKD. Where a cohort was selected from a nephrology clinic, the ESRD rate was higher than in general population studies (1.4 per 100 person-years), perhaps reflecting the clinical selection of patients at high risk of developing CKD. This could also highlight why extrapolating the experience from nephrology clinics to community practice and to patients identified through opportunistic or population screening may not be appropriate.
Policy-makers have focused on 'early' CKD and 'early' detection based on a model of progressive renal-function decline. ${ }^{12}$ From three studies, it was possible to estimate the proportion of people who did not demonstrate evidence of progressive renalfunction decline: Eriksen and Ingebretsen ${ }^{32}$ reported that $27 \%$ showed no fall in eGFR during up to 10 years' follow-up; two further studies reported that $\geq 80 \%$ did not show any worsening of CKD stage after up to 5 years' follow-up..$^{38,40}$ In practice, 
therefore, the number of patients with stage-3 CKD progressing to ESRD is likely to be low.

Looking for other indicators of underlying pathology and markers of kidney damage will be important in helping to identify which patients are at risk of a progressive course. The number of patients with CKD experiencing cardiovascular events and mortality will be much greater; as such, assessing for cardiovascular risk factors should be an important aspect of CKD patient care. As more experience is gained of the natural history of stage-3 CKD in people identified through opportunistic and population screening, it may become possible to identify those who could benefit most from more intensive management and referral to a nephrology specialist.

\section{Strengths and limitations of the study}

This review was undertaken systematically, with prespecified inclusion and exclusion criteria in order to minimise bias when selecting studies for inclusion. Thirteen studies were identified, nine of which were considered to be of good quality, but all had methodological weaknesses. Six studies used validated methods to establish the chronic nature of eGFR impairment. Although having a clear definition of chronic kidney impairment is of clinical importance and is relevant in identifying those at greater risk of progressive disease, it is important to note that population screening studies, relying on the much less specific marker of a single reduced estimated GFR, still reported the increased risks of mortality.

It has not been possible to produce a pooled estimate of the risk of death or renal disease progression for people with stage-3 CKD. There were inconsistencies in the way studies reported their findings which, along with the clinical heterogeneity in the study populations, meant that a pooled estimate would be uninterpretable. However, the risks are influenced by a range of factors - including age, sex, and comorbidities - and varied with geography (a marker for different ethnic groups and healthcare systems). Adjusted analyses suggest that stage-3 CKD is an independent risk factor for increased mortality and renal progression - a risk that increases as eGFR falls and is substantially greater for those with stage-3B disease than those with stage-3A disease.

A decision was made to exclude data from the control arms of randomised controlled trials (RCTs). Although such studies do provide a view of the natural history of the condition, the strict selection of patients to participate in them means that their outcomes are very different and difficult to generalise. For example, Jafar et $a /^{44}$ reported a meta-analysis of RCTs for ACE inhibitors in non- diabetic renal disease. From pooled RCT data for CKD stages 3-5, they reported a low all-cause mortality ( $1.2 \%$ in a mean follow-up of 2.2 years) and a relatively high progression to ESRD (11.6\%); this reflected the selection of trial participants and the difficulty in generalising such findings. In addition, very few of the intervention trials have reported their findings for stage-3 CKD separately.

\section{Conclusion}

In the UK, and internationally, there has been a major drive to detect people with 'early' CKD. The QOF supports the identification of people with stage-3 CKD in primary care, and management of their blood pressure in particular. The findings of this review highlight that, for patients identified through opportunistic detection methods where testing was undertaken for a variety of clinical indications, allcause mortality was higher than for those with no CKD and CVD was common. The risk of progression to ESRD and dialysis was substantially less.

CKD registers provide an opportunity for GPs to assess risk of CVD, and optimise care for individuals at high risk of developing CVD. For many, CKD occurs as part of a complex comorbidity cluster, with hypertension, diabetes mellitus, and CVD; as such, care should not be considered in isolation.

\section{Funding}

The work reported in this article is part of a project that was funded by the NIHR Health Technology Assessment Programme (06/75/02). The full report has been accepted for publication in Health Technology Assessment Journal (see HTA programme website for further project information). The views and opinions expressed here are those of the authors and do not necessarily reflect those of the Department of Health.

\section{Competing interests}

The authors have stated that there are none.

\section{Discuss this article}

Contribute and read comments about this article on the Discussion Forum: http://www.rcgp.org.uk/bjgp-discuss

\section{REFERENCES}

1. Cirillo M, Laurenzi M, Mancini M, et al. Low glomerular filtration in the population: prevalence, associated disorders, and awareness. Kidney Int 2006; 70: 800-806.

2. Coresh J, Selvin E, Stevens LA, et al. Prevalence of chronic kidney disease in the United States. JAMA 2007; 298: 2038-2047.

3. McCullough K, Wannamethee G, Tunstall-Pedoe H, et al. High prevalence of CKD in the Middle-aged UK population: the Scottish Heart Health Study and the British Regional Heart Study (poster). Stockholm: XLV ERA-EDTA Congress, 10-13 May 2008.

4. Nitsch D, Felber Dietrich D, Von Eckardstein A, et al. Prevalence of renal impairment and its association with cardiovascular risk factors in a general population: results of the Swiss SAPALDIA study. Nephrol Dial Transplant 2006; 21: 935-944.

5. Otero A, Gayoso P, Garcia F, de Francisco AL, EPIRCE study group. Epidemiology of chronic renal disease in the Galician population: results of the pilot Spanish EPIRCE study. Kidney Int Suppl 2005; 99: S16-S19.

6. Viktorsdottir O, Palsson R, Andresdottir MB, et al. Prevalence of chronic kidney disease based on estimated glomerular filtration rate and proteinuria in Icelandic adults. Nephrol Dial Transplant 2005; 20: 1799-1807. 
7. Ali T, Black C, Prescott G, et al. Preventing end stage renal disease: informing the development of a public health strategy. Edinburgh: Chief Scientist Office, 2007. http://www.sehd.scot.nhs.uk/cso/ Publications/ExecSumms/OctNov07/Ali.pdf (accessed 11 Apr 2010).

8. Levey AS, Andreoli SP, DuBose T, et al. Chronic kidney disease: common, harmful and treatable - World Kidney Day 2007. Am J Nephrol 2007; 27: 108-112.

9. Levin A. The advantage of a uniform terminology and staging system for chronic kidney disease (CKD). Nephrol Dial Transplant 2003; 18: 1446-1451.

10. Schoolwerth AC, Engelgau MM, Hostetter TH, et al. Chronic kidney disease: a public health problem that needs a public health action plan. Prev Chronic Dis 2006; 3: A57.

11. Saydah S, Eberhardt M, Rios-Burrows N, et al. Prevalence of chronic kidney disease and associated risk factors — United States, 19992004. JAMA 2007; 297: 1767-1768.

12. Levey AS, Coresh J, Balk E, et al. National Kidney Foundation practice guidelines for chronic kidney disease: evaluation, classification, and stratification. Ann Intern Med 2003; 139: 137-147.

13. UK and Scottish Renal Associations. Consensus statement on management of early CKD, February 2007. Edinburgh: Royal College of Physicians of Edinburgh, 2007. http://www.renal.org/CKDguide/consensus.html (accessed 11 Apr 2010).

14. Lamb EJ. United Kingdom guidelines for chronic kidney disease. Scand J Clin Lab Invest Suppl 2008; 241: 16-22.

15. National Institute for Health and Clinical Excellence. Chronic kidney disease: early identification and management of chronic kidney disease in adults in primary and secondary care. London: NICE, 2008. http://guidance.nice.org.uk/CG73 (accessed 11 Apr 2010).

16. Scottish Intercollegiate Guidelines Network. Diagnosis and management of chronic kidney disease. Edinburgh: SIGN, 2008. http://www.sign.ac.uk/guidelines/fulltext/103/index.html (accessed 11 Apr 2010).

17. Heffernan C. Screening for chronic kidney disease: an evidence based review for the National Screening Committee. London: UK National Screening Committee, 2008. http://www.library.nhs.uk/screening/ ViewResource.aspx?resID=301152 (accessed 11 Apr 2010).

18. McCullough PA, Li S, Jurkovitz CT, et al. CKD and cardiovascular disease in screened high-risk volunteer and general populations: the Kidney Early Evaluation Program (KEEP) and National Health and Nutrition Examination Survey (NHANES) 1999-2004. Am J Kidney Dis 2008; 51: S38-S45.

19. Klebe B, Irving J, Stevens PE, et al. The cost of implementing UK guidelines for the management of chronic kidney disease. Nephrol Dial Transplant 2007; 22: 2504-2512.

20. Feehally J, Griffith KE, Lamb EJ, et al. Early detection of chronic kidney disease. BMJ 2008; 337: a1618.

21. Poggio ED, Rule AD. A critical evaluation of chronic kidney disease — should isolated reduced estimated glomerular filtration rate be considered a 'disease'? Nephrol Dial Transplant 2009; 24: 698-700.

22. Anonymous. CRD's guidance for undertaking reviews in health care. York: Centre for Reviews and Dissemination, 2008. http://www.york.ac.uk/inst/crd/pdf/Systematic_Reviews.pdf (accessed 11 Apr 2010).

23. Anonymous. Critical Appraisal Skills Programme: making sense of evidence. 12 questions to help you make sense of a cohort study. Oxford: Public Health Resource Unit, 2008.

http://www.phru.nhs.uk/Doc_Links/cohort\%2012\%20questions.pdf (accessed 11 Apr 2010).

24. Downs SH, Black N. The feasibility of creating a checklist for the assessment of the methodological quality both of randomised and non-randomised studies of health care interventions. J Epidemiol Community Health 1998; 52: 377-384.

25. Sanderson S, Tatt ID, Higgins JP. Tools for assessing quality and susceptibility to bias in observational studies in epidemiology: a systematic review and annotated bibliography. Int J Epidemiol 2007; 36: 666-676.

26. Wells GA, Shea B, O'Connell D, et al. The Newcastle-Ottawa Scal (NOS) for assessing the quality of nonrandomised studies in metaanalyses.

http://www.ohri.ca/programs/clinical_epidemiology/oxford.htm (accessed 10 May 2010).

27. Hallan SI, Dahl K, Oien CM, et al. Screening strategies for chronic kidney disease in the general population: follow-up of cross sectional health survey. BMJ 2006; 333: 1047-1050.

28. Hallan S, Astor B, Romundstad S, et al. Association of kidney function and albuminuria with cardiovascular mortality in older vs younger individuals: The HUNT II Study. Arch Intern Med 2007; 167: 2490-2496.

29. Hallan SI, Ritz E, Lydersen S, et al. Combining GFR and albuminuria to classify CKD improves prediction of ESRD. J Am Soc Nephrol 2009; 20: 1069-1077.

30. Keith DS, Nichols GA, Gullion CM, et al. Longitudinal follow-up and outcomes among a population with chronic kidney disease in a large managed care organization. Arch Intern Med 2004; 164: 659-663.

31. Gullion CM, Keith DS, Nichols GA, Smith DH. Impact of comorbidities on mortality in managed care patients with CKD. Am Kidney Dis 2006; 48: 212-220.

32. Eriksen BO, Ingebretsen OC. The progression of chronic kidney disease: a 10-year population-based study of the effects of gender and age. Kidney Int 2006; 69: 375-382.

33. Eriksen BO, Ingebretsen OC. In chronic kidney disease staging the use of the chronicity criterion affects prognosis and the rate of progression. Kidney Int 2007; 72: 1242-1248.

34. Chiu YL, Chien KL, Lin SL, et al. Outcomes of stage 3-5 chronic kidney disease before end-stage renal disease at a single center in Taiwan. Nephron Clin Pract 2008; 109: c109-c118.

35. Djamali A, Kendziorski C, Brazy PC, Becker BN. Disease progression and outcomes in chronic kidney disease and renal transplantation. Kidney Int 2003; 64: 1800-1807.

36. Go AS, Chertow GM, Fan D, et al. Chronic kidney disease and the risks of death, cardiovascular events, and hospitalization. New Engl J Med 2004; 351: 1296-1305.

37. Hemmelgarn BR, Zhang J, Manns BJ, et al. Progression of kidney dysfunction in the community-dwelling elderly. Kidney Int 2006; 69: 2155-2161.

38. Khatami Z, Handley G, Narayanan K, Weaver JU. Applicability of estimated glomerular filtration rate in stratifying chronic kidney disease. Scand J Clin Lab Invest 2007; 67: 297-305.

39. O'Hare AM, Bertenthal D, Covinsky KE, et al. Mortality risk stratification in chronic kidney disease: one size for all ages? J Am Soc Nephrol 2006; 17: 846-853.

40. Orlando LA, Owen WF, Matchar DB. Relationship between nephrologist care and progression of chronic kidney disease. $N C$ Med J 2007; 68: 9-16.

41. Brantsma AH, Bakker SJ, Hillege HL, et al. Cardiovascular and renal outcome in subjects with K/DOQI stage 1-3 chronic kidney disease: the importance of urinary albumin excretion. Nephrol Dial Transplant 2008; 23: 3851-3858

42. Imai E, Horio M, Yamagata K, et al. Slower decline of glomerular filtration rate in the Japanese general population: a longitudinal 10year follow-up study. Hypertens Res 2008; 31: 433-441.

43. Wen CP, Cheng TY, Tsai MK, et al. All-cause mortality attributable to chronic kidney disease: a prospective cohort study based on 462293 adults in Taiwan. Lancet 2008; 371: 2173-2182.

44. Jafar TH, Schmid CH, Landa M, et al. Angiotensin-converting enzyme inhibitors and progression of nondiabetic renal disease. A meta-analysis of patient-level data. Ann Intern Med 2001; 135: 73-87. 